\title{
A memória e a infância revisitada por Bartolomeu Campos de Queirós
}

\section{Memory and childhood revisited by Bartolomeu Campos de Queirós}

\section{La memoria y la niñez revisitada por Bartolomeu Campos de Queirós}

\footnotetext{
(19) Cássia regina machado alves Universidade Estadual de Montes Claros (UNIMONTES), Montes Claros, Minas Gerais, Brasil.

E-mail: cassia.alves@ifmg.edu.br

(9) Telma borges Universidade Federal de Minas Gerais (UFMG), Pampulha, Minas Gerais, Brasil. E-mail: t2Im1b3rg2s@yahoo.com
}

Resumo: Este artigo visa a analisar aspectos importantes acerca da memória em Indez, em Ler, escrever e fazer conta de cabeça e no conto "Foram muitos, os professores," de Bartolomeu Campos de Queirós. De natureza memorialística, as narrativas resgatam o período da infância do autor mineiro vivida entre as cidades de Papagaios e Pitangui. Analisamos os conceitos relacionados à Memória e aos eventos narrados pelo autor, os quais tratam de suas experiências de infância, resgatadas para produzir a escrita da sua história familiar e da coletividade em que vivia, produzindo, no tempo da escrita, uma releitura desses eventos do passado.

Palavras-Chave: Bartolomeu Campos de Queirós. Memória. Infância.

Abstract: This article aims to analyze important aspects about the memory in Indez, in Ler, escrever e fazer conta de cabeça and the story "Foram 
muitos, os professores" by Bartolomeu Campos de Queirós. In memorialistic source narratives rescued miner author period of childhood lived among the cities of Papagaios and Pitangui. We analyze the concepts about memory and relate to events in which the author recounts his childhood experiences rescued from memory to produce writing your family history and the community in which he lived, producing at the time of writing, a rereading of those events of the past.

Keywords: Bartolomeu Campos de Queirós. Memory. Childhood.

Resumen: Este articulo analiza aspectos importantes sobre la memoria en Indez, Ler, escrever e fazer conta de cabeça y en la historia "Foram muitos, os professores," de Bartolomeu Campos de Queirós. De origen memorialista las narrativas rescatan el período de la niñez del autor vivida entre las ciudades de Papagaios y Pitanguí. Se analizan los conceptos acerca de la memoria y la relacionamos con los eventos en los que el autor relata sus experiencias de la niñez rescatados de la memoria para producir la escritura de su historia familiar y la comunidad en la que vivía produciendo una nueva lectura de los acontecimientos del pasado.

Palabras-Ilave: Bartolomeu Campos de Queirós. Memoria. Niñez.

Submetido em 12 de março de 2019.

Aceito em 23 de agosto de 2019.

Publicado em 05 de fevereiro de 2020. 
Gostaríamos de ter um contínuo de atos e de vida para contar, mas nossa alma não guardou uma lembrança fiel de nossa idade nem a verdadeira medida da extensão de nossa viagem ao longo dos anos; guardou apenas a lembrança dos acontecimentos que criaram instantes decisivos de nosso passado. Em nossa confidência, todos os acontecimentos são assim reduzidos à sua raiz em um instante.

Gaston Bachelard

Em $A$ arte da memória, Frances Yates menciona uma definição muito apropriada de memória formulada por Boncompagno de Signa, autor de Rethorica Novissima, livro escrito em 1235:

A memória é um glorioso e admirável dom da natureza, pelo qual recordamos as coisas passadas, compreendemos as presentes e contemplamos as futuras, por meio de sua semelhança com as coisas passadas. (Boncompagno, apud YATES, 2007, p. 81).

Segundo Jacy Alves de Seixas,

[a] memória é portanto algo que "atravessa", que "vence obstáculos", que "emerge", que irrompe: os sentimentos associados a este percurso são ambíguos, mas estão sempre presentes. Não há memória involuntária que não venha carregada de afetividade [...]. (SEIXAS, 2009, p. 47).

Nossa afetividade interfere nas lembranças que estão gravadas na memória e abarca sentimentos, emoções e impressões produzidos pelos fatos vividos, em função do momento em que tais fatos ocorreram. Visto sob esse prisma, o memorialista, ao narrar algo vivido, traz à tona sua consciência individual de fatos ocorridos consigo, os quais resultaram em lembranças gravadas em sua memória; as emoções e outros sentimentos produzidos pelo contexto em que ocorreram os fatos permitem que esse passado seja recriado e seja aportado no presente, utilizando-se da força da linguagem para modificá-lo na narrativa. 
Frances Yates mostra que Aristóteles concebia a memória como sendo a faculdade de armazenar informações; paralelamente a esse conceito, o filósofo a distinguia da reminiscência, porque esta seria algo mais profundo, relacionada à parte racional da alma. A reminiscência, portanto, vai além do ato de lembrar o passado conservado na memória; é o esforço voluntário da evocação, que atinge níveis espirituais e intelectuais relacionados à nossa intimidade; carrega nossa afetividade e abarca sentimentos, emoções e impressões.

Quando Seixas postula que a memória "introduz o passado no presente sem modificá-lo, mas necessariamente atualizando-o" (SEIXAS, 2009, p. 50), evidencia a percepção de que a memória possibilita a construção e a reconstrução da nossa própria existência, quando reconstituímos o passado histórico não só na nossa própria perspectiva, mas também na dos outros com quem convivemos.

Destarte, há a construção da identidade através da narrativa de si, que é tornada possível na medida em que o autor situa os acontecimentos ocorridos numa perspectiva individual; entretanto, inseridos, por sua vez, na amplidão de uma coletividade, demonstrando as transformações que ocorrem no indivíduo a partir do que essa coletividade e o contexto em que esta se insere representam para ele.

Maurice Halbwacks argumenta que a memória coletiva também contém componentes individuais, porque, ainda que nossas memórias partam da nossa individualidade, elas estão sempre permeadas por um contexto social. Para esse sociólogo francês, só é possível lembrarmo-nos de acontecimentos quando nos situamos no ponto de vista de um ou de mais grupos dos quais fazíamos parte no momento em que ocorreram. Assim, como não é possível separar nossa história da história do entorno social no qual estamos inseridos, não se pode separar a memória individual da memória coletiva, porque a memória individual está impregnada do meio social no qual vivemos. 
A memória e a infância revisitadas por Bartolomeu Campos de Queirós Cássia Regina Machado Alves • Telma Borges

A literatura contempla uma diversidade de estilos adotados por diferentes autores. A literatura memorialística, em especial, exerce função literária e histórica ao estabelecer um paralelo entre o passado e o presente, situando a consciência individual de quem escreve dentro de uma coletividade. Mais do que relembrar suas histórias, narrando-as através da linguagem literária, o memorialista as organiza e as (re)interpreta, reinventando-as e reencontrando-se naqueles tempo e espaço. Nesse sentido, as lembranças reconstroem não somente os fatos que se materializam na ação da transcrição escrita, mas também os sentimentos e as impressões que se configuram em particularidades que marcaram o autor no momento em que ocorreram e vêm à tona a partir dessas particularidades. Maurice Halbwacks, em A memória coletiva, assim exemplifica:

[é] assim que, quando se entra pela primeira vez em um quarto na boca da noite, quando vemos as paredes, móveis e todos os objetos mergulhados dentro de uma semi-obscuridade, essas formas fantásticas ou misteriosas permanecem na nossa memória como o quadro apenas real da nossa inquietude, de surpresa ou de tristeza que nos acompanhava no momento em que elas feriam nossos olhares. (HALBWACHS, 1990, p. 35).

Assim, as lembranças que se fixam em nossa memória são carregadas do sentido produzido pelo contexto em que ocorreram e desencadeiam outros fatos que dão origem às impressões, as quais variam conforme o momento particular de cada um.

O autor mineiro Bartolomeu Campos de Queirós nasceu em 1944, na cidade de Papagaios. Viveu a infância nessa pequena cidade e em Pitangui/MG, vindo a falecer em 16 de janeiro de 2012, na capital mineira, onde passou grande parte da sua vida. Em entrevista à Revista Palavra ${ }^{1}$, o autor concebe a memória como um "grande patrimônio" que guarda tanto "o que vivemos" quanto "o

1 Entrevista editada a partir da entrevista original concedida por Bartolomeu Campos de Queirós, em 07 de junho de 2011 , ao Paiol Literário, projeto cultural promovido pelo jornal Rascunho, em parceria com a Fundação Cultural de Curitiba, o SESI Paraná e a FIEP. 
que sonhamos", e é a literatura que torna possível o diálogo entre o sonho e a realidade. Segundo ele, "com a literatura, esse mundo sonhado consegue falar. O texto literário é um texto que também dá voz ao leitor" (QUEIRÓS, 2012, p. 19).

Assim, a literatura possibilita expressar sobre o que o autor carrega consigo, concretizando, através da linguagem, a representação de imagens que se mantinham em suas lembranças como sonho. Com sua capacidade criadora, o autor preenche as lacunas existentes nessas lembranças, lançando as "pontes", compondo as imagens e fazendo as montagens necessárias, conforme postula Eliana Yunes:

O exercício da recordação, imperfeito por excelência, serve à perfeição para construir, com todas as correções, a biografia de nossos sonhos ou pesadelos. Sobre os lapsos, lançamos pontes; sobre os recalques, compomos imagens, e vamos montando, à luz do desejo e do imaginário, a narração com que queremos nos ver identificados. (YUNES, 2012, p. 37).

Em Indez, em Ler, escrever e fazer conta de cabeça e no conto "Foram muitos, os professores," Bartolomeu Campos de Queirós resgata da memória sua infância e relata a trajetória de vida de suas personagens, utilizando-se de prosa poética para reconstruir, pela via da ficção, o passado e, de modo simultâneo, apresentá-lo no tempo da enunciação. Expressando detalhes muitas vezes comuns à infância dos leitores, o autor, com um olhar reflexivo sobre as pessoas, a natureza e o mundo, reconstrói cenários em que vivia uma família interiorana simples. Dispondo da memória para representar a infância como algo que faz parte do brincar, do se desenvolver, do crescer e do aprender através da dúvida, da curiosidade, da suposição - tudo acontecendo simultaneamente - Bartolomeu Campos de Queirós apresenta, literariamente, os sentimentos e a afetuosidade que cada fato narrado produziu.

Percebe-se, nessas narrativas memorialistas, que o que foi vivido e sonhado se depara e dialoga com a realidade presente, en- 
contrando, na linguagem, o instrumento que Ihe dá completude. O autor, através da sua capacidade de transportar para o leitor os sentimentos e a afetividade de suas lembranças, consegue envolvê-lo em seu próprio universo infantil, que passa a ser também daquele que lê; acrescenta, pois, o que as lembranças não guardaram, o que ficou esquecido ou o que precisa ser recuperado.

Ao trazer à tona lembranças que são marcadas pela ludicidade própria da infância, o autor evoca nessas narrativas uma reflexão sobre o vivido e sua relação com o presente, reconstruindo sua compreensão dos acontecimentos. Nota-se que, no processo de rememoração do vivido, o intelecto do adulto e o momento da escrita interferem nas memórias narradas pelo autor-personagem, que reelabora sua percepção sobre os eventos e sua compreensão sobre o mundo e sobre sua própria existência nele.

Em Indez, temos a reconstrução do cenário rural em que se situam a casa e a escola, onde eram comuns as rotinas da natureza, cujas estações de que se tinha conhecimento eram apenas a da seca e a da chuva. Naquele "pedaço de mundo aberto", viviam Antônio, os pais e os irmãos "aprendendo com as estações, as mudanças, as perdas, os enxertos. Assistiam às florações, podavam as árvores em luas certas e falavam pouco de outras felicidades" (QUEIRÓS, 2004, p. 14).

Na descrição da casa, temos a impressão de estarmos passando, junto com o narrador, pelos cenários que vão sendo reconstruídos a partir das lembranças guardadas em sua memória:

Era uma casa feita em adobe, cheia de portas e janelas que se abriam para um grande curral, com sombra e os verdes de vários tons. Caiada em branco, ela acolhia o vento, o sol, a lua, a família. Na sala de visita, sob a proteção do Coração de Jesus e de Maria, balançavam outros redondos retratos de antepassados: o avô de óculos e bengala, a bisavó entre flores, o pai ainda moço com bigode e gravata-borboleta, que os meninos aprenderam a chamar de "gravoleta borbotinha" (QUEIRÓS, 2004, p. 13). 
Observamos que a memória voluntária traz à tona o lugar com suas características físicas, o que permite ao autor a descrição dos objetos, dos móveis, das cores. Mistura-se a essa descrição as sensações que o lugar lhe causava: a casa como lar, local de acolhimento e abrigo quase sagrado, sob a presença do quadro das figuras sacras na parede. A descrição estabelece ainda o vínculo das recordações do autor ao sentimento experimentado na estrutura familiar: lembrança afetuosa dos retratos do avô, da bisavó e do pai. O narrador continua com o detalhamento das imagens fixadas em sua memória, através do lugar que cada objeto ocupava dentro de um determinado espaço da casa:

Na sala de dentro, mesa grande com cadeiras de palhinha. Num canto, a cristaleira com brilhos de copos, cálices, licoreiras de vidro. Do outro lado ficava o filtro de barro suando água fresca buscada na mina. Água misteriosa brotando entre pedras e raízes... Desta sala avistava-se a cozinha com o fogão de lenha e mais prateleiras, enfeitadas com jornal repicado, onde potes e latas areadas guardavam doces e suspiros. (QUEIRÓS, 2004, p. 14-15).

O excerto acima merece ser analisado à luz do que se conhece como a arte da memória ou mnemotécnica, por meio da qual podemos fixar os fatos, associando-os a imagens situadas em determinados lugares na memória. Ao passarmos mentalmente por tais lugares, onde essas imagens estão guardadas, as lembranças afloram.

Essa arte teve suas origens na Grécia antiga, e é contada através de um episódio vivido pelo poeta grego Simônides de Ceos (556 a. C. - 468 a. C.). Único sobrevivente de um desabamento durante um banquete na Tessália, Simônides ajudou a identificar os mortos, porque havia fixado em sua memória o lugar que cada convidado ocupara à mesa. Esse acontecimento o levou a sugerir que havia descoberto os pressupostos da arte da memória, pois sua lembrança só foi possível devido à associação que fez entre as imagens das pessoas e os lugares em que cada uma estivera 
sentada à mesa; assim, por meio disso, fixou as imagens em sua mente, associando o fato à eficiência dos sentidos, dos quais a visão foi essencial na fixação das imagens na memória.

Queirós nos traz muito da técnica de Simônides. Observemos que o autor visualiza o lugar como um todo e situa cada objeto em um determinado lugar nesse todo: ao centro, uma mesa; de um lado, uma cristaleira; em um canto, o filtro. Na cozinha, os lugares também são delimitados pela presença do fogão de lenha e das prateleiras. Curiosamente, ao mencionar as prateleiras, o autor acrescenta-lhes os potes e, dentro desses potes, os doces. Com a cristaleira, essa mesma dinâmica é realizada, com os copos, os cálices e as licoreiras, o que nos oferece a sensação de que suas lembranças afloram de forma desencadeada, sendo uma lembrança preenchida por outra. Certamente, há o preenchimento ficcional por parte do autor, na tentativa de completar um ou outro dado que o esquecimento não Ihe permitiu lembrar.

Com acréscimo da ficção, o narrador de Indez representa sua personagem central: Antônio. É certo que, aqui, não se tratam de lembranças, mas do "ouvir falar", da narrativa das histórias familiares contadas pelos adultos. Com os testemunhos dos adultos, o narrador relata a origem do menino Antônio, que nasceu na estação das águas, cercado de amor, cuidados e proteção desde o nascimento e - "também pudera, quem não ia gostar de um menino nascido de improviso, sem respeitar o calendário?" (QUEIRÓS, 2004 , p. 11) - por ser prematuro de sete meses, o menino era muito suscetível a doenças, e necessitava de mais cuidados e zelo com sua saúde.

Esses cuidados aparecem na narrativa cercados de superstições, crendices, tratamentos caseiros e orações benzedeiras, próprios da crença popular e da tradição oral, passados de geração em geração e comuns a uma família interiorana. Em meio a uma crise de coqueluche, a mãe levantava-se bem cedo e com o menino no colo, passeava pelo quintal para aspirar o cheiro do curral, ou adicionava ao leite uma ferradura em brasa, na crença de que esses cuidados curariam "tosse comprida". 
Temos, mais uma vez, a ação da memória coletiva atuando sobre a memória individual. As crendices da cultura popular, que fizeram parte do universo infantil do autor, são comuns em todo o Brasil, e variam de região para região. Na sua infância, que se deu nas décadas de 1940 a 1950, essa memória cultural é também a de um tempo no qual a medicina oficial ainda não havia chegado ao interior de Minas com toda sua força. Segundo Sulla Mino, no artigo "Superstições - parte I", crendices e superstições

\begin{abstract}
[...] são vestígios de um passado remoto, em que o ser humano tinha uma visão mágica do mundo, acreditando que diversos fatores sobrenaturais podiam interferir diretamente no seu dia. Esse modo de pensar foi-se transmitindo, em especial entre as camadas populares, que foram mantidas à margem da evolução do conhecimento científico. (MINO, 2012, p. 6).
\end{abstract}

As simpatias e as superstições da crendice popular brasileira aparecem em vários momentos das narrativas: a água do sino da igreja curava fala atrasada; o chocalho de cobra pendurado no pescoço ajudava o menino a não urinar na cama; o local onde fosse enterrado o umbigo do recém-nascido determinaria o que ele seria no futuro: "[s]e no jardim com flores, a menina seria bela e boa jardineira. Se na horta, o menino seria lavrador e, se no curral, boiadeiro" (QUEIRÓS, 2004, p. 9). Parece-nos que a memória do adulto falando de sua infância revela, também, a intencionalidade do autor em divulgar e em preservar a maneira de ser de uma geração, da coletividade na qual sua história de vida e a de muitos de seus leitores se situa.

As festas e os rituais religiosos também são comuns em todo o território brasileiro. Em Minas, essas manifestações religiosas são elementos que caracterizam a tradição popular do estado constituindo, portanto, parte de sua memória cultural e da de seu povo. Em vários municípios são realizadas festas em homenagem aos santos católicos e aos santos de origem africana, provenientes do 
candomblé e da umbanda. Há levantamentos de mastro, coroações a Nossa Senhora e quermesses com comidas típicas, ocasiões que se configuram como momentos de interação da comunidade local.

Conforme Halbwacks, "toda religião tem também sua história, ou antes, há uma memória religiosa feita de tradições que remontam a acontecimentos geralmente muito distantes no passado, e que aconteceram em lugares determinados" (HALBWACKS, 1990, p. 157).

As festas religiosas brasileiras incluem-se nessa perspectiva descrita por Halbwacks, pois representam cenas de acontecimentos do passado, envolvendo vestimentas, músicas e danças típicas de cada região, que resgatam a memória histórica do lugar e a de seus habitantes, seja exaltando as boas colheitas - como a festa das rosas, em Barbacena - seja homenageando os santos e as santas, como os catopês e as congadas; ou ainda, no caso das marujadas, resgatando a memória dos feitos marítimos dos portugueses representados nas "Festas de Agosto", como ocorrem em Montes Claros no norte de Minas Gerais. São manifestações que buscam resgatar, preservar e perpetuar a memória histórica das cidades e dos lugarejos por meio da representação da fé e da devoção presentes na memória coletiva dos habitantes do lugar.

Muitas dessas manifestações fizeram parte da infância narrada por Bartolomeu Campos de Queirós, que detalha as tradições católicas das quais a família participava com devoção: festas religiosas na semana santa; a festas juninas (Santo Antônio, São João, São Pedro e Santana); a coroações, do mês de maio, a Nossa Senhora; no Natal, os preparativos da mãe para armar o presépio, cumprindo-se o ritual de armar a cena do nascimento de Jesus, quando a mãe construía "a serra com os vasos de folhagens escondidos entre papéis e dobras. Depois vinham os bichos colocados entre moitas, sobre pedras, altos galhos" (QUEIRÓs, 2004, p. 69). Há também o relato dos medos infantis na comunhão: "se a hóstia tocar no dente, o gosto de sangue vem na hora, diziam. E o medo de morder Deus aumentava" (QUEIRÓS, 2004, p. 87). 
Pode-se constatar que essas crendices estão associadas também às primeiras alusões feitas pela memória à religiosidade, pois a memória sempre esteve associada a questões religiosas. Encontramos muito sobre o assunto em $A$ arte da Memória, de Frances Yates. Nos estudos da historiadora, percebemos que, no período medieval, a tradição cristã da memória estava centrada na lembrança do céu e do inferno, tendo sido representada principalmente nas pinturas e, posteriormente, publicada em livros. São exemplos desse período as pinturas de Giotto, que representavam a inveja e a caridade, e o famoso "Mapa do Inferno", uma das partes da Divina Comédia de Dante Alighieri, que representava alegoricamente o que se acreditava ser o conceito de inferno à época, contendo, por exemplo, os círculos da luxúria, da gula, da avareza e da ira - pecados dignos de punição.

Essas alusões ao céu e ao inferno, assim como as concepções que os associam às dimensões do bem e do mal e, consequentemente, a castigos e punições de um período tão longínquo da história, certamente influenciaram, no decorrer dos séculos, as sociedades modernas. O narrador-personagem destaca na narrativa os medos que o acometiam: medo de castigos divinos, medo de pecar, que lembra muito dessa estrutura de pensamento desenvolvida no imaginário medieval.

Tanto em Indez, em Ler, escrever e fazer conta de cabeça quanto no conto "Foram muitos, os professores", Queirós compartilha com o leitor os sentimentos que afloraram no personagem quando este foi para a escola que, a princípio, foi o medo, quando se achou sozinho, separado das irmãs. A primeira escola, "cercada de montanhas por todos os cantos, [...] um lugar tranquilo, visitado pelo mugido do gado, canto de passarinho, gritos de grilos e cigarras" (QUEIRÓS, 2004, p. 71-72), é caracterizada pela forte presença da natureza. Observemos que a memória é seletiva, pois, nesse trecho, o narrador retém da escola o que se encontra ao seu redor, e não sua representação estrutural, como faz com a casa. Comparativamente, são dois ambientes distintos: a casa, além de espaço físico composto por cadeiras, mesas, sala, cozinha, era também 
abrigo, conforto, sentimento, afetuosidade. Em relação à escola, o autor descreve os elementos externos que, na sua perspectiva individual, foram mais marcantes. O autor traz para o texto literário a particularidade, que é seu ponto de vista do que a memória seletiva Ihe permitiu narrar.

No fragmento a seguir, o narrador descreve alguns elementos físicos da sala de aula que, a nosso ver, para a criança, parece ser um ambiente deslocado da escola em si e, mais uma vez, se detém nos elementos externos que, na sua consciência individual, ficaram associados ao ambiente de aprendizagem que era a sala:

Era uma sala caiada de branco, com janelas para os dois lados e chão coberto de cimento liso. Sem forro, tornava-se mais clara e limpa. [...] Em quatro mesas grandes os alunos se dividiam conforme as séries: primeira, segunda, terceira e quarta. Lá fora ficava uma coberta com fogão de lenha, o pote de água fresca com um copo cheio de pontas para ninguém babujar. Do outro lado, os canteiros onde cresciam couves, abóboras, quiabos, taiobas, cebolinhas, salsas, mandiocas, carás. (QUEIRÓs, 2004, p. 71).

O elemento fundamental para a criança era seu mundo, o universo no qual ela já estava inserida (a natureza); a sala de aula e a escola eram acréscimos a esse universo.

As memórias de Bartolomeu Campos de Queirós carregam também as perdas afetivas, que refletem no adulto que narra. Em Indez, o menino aprende muito cedo a conviver com a perda da avó, sentida quando "a mãe, com roupa escura, costurava tirinhas de pano preto nas mangas das camisas do pai." (QUEIRÓS, 2004, p. 64). Outra perda foi a da convivência familiar, que se deu quando o menino teve que ir morar na casa do avô, na cidade, para continuar os estudos em outra escola, e percebeu que "tudo ia ficando para trás: o gado, os córregos, as pontes, as cercas, as árvores" (QUEIRÓS, 2004, p. 92).

As lembranças das perdas que o narrador relata são aquelas guardadas espontaneamente, ou seja, que nos marcaram de al- 
guma forma; e são as que ficam mais fortes em nossa memória. Sobre isso, o francês Henri Bergson, em Matéria e Memória, diz ser a relação existente entre imagem e memória, pois é através das imagens que são formados os acontecimentos fixados em nossa mente como imagem-lembrança, que favorece o reconhecimento dos objetos. Seria, então, na imagem-lembrança que se situariam os fatos de nossa vida passada. Essas imagens-lembrança são narradas por Bartolomeu Campos de Queirós através da representação simbólica da casa do avô, sem a presença da avó, e das roupas escuras e das tirinhas pretas que a mãe costurava nas roupas em sinal de luto - imagens-lembrança que o marcaram e que se relacionam às suas perdas.

Em Ler, escrever e fazer conta de cabeça, a perda da mãe revela uma narrativa que vai ao encontro da tristeza do menino Antônio, de Indez. A mãe, acometida por uma doença grave, definha e morre, preenchendo de vazio os familiares, sua infância e sua casa, que "ficou maior e cheia de silêncio". Um silêncio que "parecia se esforçar para não acordar quem deveria dormir por toda a vida" (QUEIRÓS, 2001, p. 101).

Vejamos, no excerto a seguir, a profundidade com que o narrador-personagem traduz o sentimento de perda, e como as imagens-lembrança permitem expressar essa profundidade:

Entrei de manso. Vi suas mãos afogadas sobre os panos da cama, como se não mais tivessem comando. Estavam imóveis. Lembrei-me do ferro de brasa acariciando a roupa, da colher de pau raspando o fundo do tacho, do regador fazendo chuva por sobre as hortaliças, da espuma no tanque esfregando nossas manchas, do pão repartido em seis, pela manhã. Um resto de sol morno do crepúsculo entrava pela janela sem muita luz, filtrado pela tristeza que arrastava as nuvens pelo céu, naquela hora. Insisti meu olhar sobre suas mãos e não vi as meias-luas nascendo em suas unhas. O padre Viegas chegou com a latinha de água-benta e o missal. (QUEIRÓS, 2004, p. 98). 
Primeiro, o narrador-personagem relembra a representação simbólica da ação que o levou a constatar a morte da mãe: as mãos dela imóveis na cama. A primeira imagem que registra é a das mãos, e não do corpo em si, num processo de elaboração mental da criança diante do acontecimento. As mãos, para ele, representam a vida e, no caso acima, a falta dela. Isso fica evidente no extrato que vem logo a seguir, quando relembra as ações que a mãe praticava em vida com as mãos: passar roupa, cozinhar, moIhar as plantas, lavar a roupa, cuidar da família.

As lembranças apresentadas pelo narrador-personagem e a associação que ele faz das mãos com a vida são fornecidas por suas lembranças, uma puxando a outra; ou seja, as lembranças das mãos imóveis puxam as lembranças das mãos ágeis e os sentimentos provocados no autor por essas ações da mãe em vida cuidado, carinho, afeto, família. Essas estruturas de que o autor se vale se parecem com um encaixe, como se cada lembrança estivesse guardada em uma caixa, e cada caixa dentro de uma outra. Ao abrir uma caixa, outra caixa com outras lembranças se oferece à visão; abrindo essa outra caixa, novas e novas caixas vão surgindo. O autor elabora uma rememoração na perspectiva dos encaixes.

A seguir, aparece, no mesmo excerto, o tempo revisitado, quando o adulto relembra o momento em um fim de tarde, que ele também colore com as tintas da dor, da tristeza. Pode ser que o tempo não se encontrasse dessa forma, mas, na memória do adulto, é assim que as lembranças desse dia lancinante foram guardadas. Aqui, são as palavras de um adulto que amarga a dor de uma perda que ainda o incomoda.

Por fim, ao descrever novamente, nas mãos, as meias-luas das unhas de que a mãe lhe falava, ele parece ter sido acometido pela memória involuntária, despertada pela insistência do olhar sobre as mãos imóveis da mãe e pelos sentimentos que emergiram nesse percurso e que aparecem no trecho que vem logo a seguir - "e não vi as meias-luas nascendo em suas unhas" - representando a confirmação do que o menino constatou logo que entrou no quarto. O padre, com os aparatos religiosos, vem, na visão do menino, 
consumar o irremediável, a morte da mãe, mencionada no início da citação, fragmento que foi entrecortado pelas lembranças das mãos que simbolizavam a vida.

As mãos, para o autor, representam um elemento fundamental na composição da imagem da mãe, pois, em outros momentos da narrativa, como veremos mais adiante, elas voltam a aparecer simbolizando seu fazer diário, que possibilitava a criação de mundos possíveis para os filhos e para a família.

Vale destacar que Queirós narra sua tristeza da infância na perspectiva de um adulto que ainda a sente no momento da enunciação, como uma ferida incurável que faz com que ele tenha sempre que se reconstruir através das respostas que o passado oferece à construção/reconstrução do presente. Percebemos, na descrição exposta, que o autor transcreve suas memórias no mesmo ritmo em que as lembranças vão aparecendo em sua mente, uma a uma, apontando o rumo do momento lembrado.

Nas narrativas, temos a representação de um menino cheio de dúvidas e de curiosidades, que está sempre em busca de explicações para tudo, como que a tentar descobrir o significado das coisas para reconstruí-las a seu modo, com seu conhecimento de mundo.

O próprio título do livro, Indez, sugere isso. A palavra "indez" significa o ovo deixado no ninho para que a galinha saiba onde deve voltar a botar novamente. Metaforicamente, o autor revela sua própria reconstrução memorialística em Antônio, que tinha vontade de pegar também o indez, para que "a galinha, perdendo a direção do ninho, quem sabe, constru[ísse] outro, em lugar longe, mais oculto, mais secreto" (QUEIRÓS, 2004, p. 51). Nessa dinâmica, o autor, ao reconstruir seu passado, reconstrói suas origens pela via da ficção e pelas lembranças que guardou na memória e que emergem no reconto, como seu ninho, seu indez.

É interessante observarmos que as figuras afetuosas que marcaram a infância do autor são representadas nos dois livros aqui em estudo e no conto. A mãe, o pai, o avô e a professora das pri- 
A memória e a infância revisitadas por Bartolomeu Campos de Queirós Cássia Regina Machado Alves • Telma Borges

meiras séries são reinventados em cada narrativa, como rearranjos de memória do sujeito que lembra. Em algumas entrevistas, Bartolomeu Campos de Queirós cita os mesmos episódios narrados nos livros, ao falar da mãe, do pai, do avô e da professora. Para ele, à memória junta-se a fantasia que o adulto tem dentro de si como algo real. Pode-se inferir daí que sua habilidade de recompor, tendo como suporte a memória ficcional, permite que ele reinvente essas personagens em cada uma dessas narrativas, através de construções bem elaboradas que nos fazem reconhecer essas figuras de modo similar nos episódios narrados.

A figura doce da mãe é trazida pelas lembranças do narrador, com muito afeto, em Indez. A mãe era quem encenava brincadeiras, quem Ihes pregava peças, fritando bolinhos de algodão como se fossem de verdade, no dia primeiro de abril; na estrada, para abrandar a distância e esquecer o cansaço, "ela brincava de contar as estacas da cerca"; ensinava os filhos a brincarem de "correr atrás da sombra, de pular carniça, de andar no ritmo dos escravos de Jó", e dizia-Ihes sabiamente que "brincar encurta[va] caminho" (QUEIRÓs, 2004, p. 57).

O narrador traz os detalhes das brincadeiras que a mãe encenava recheando de ludicidade, de fantasia e de encantamento a infância dos filhos. Em uma tarde de domingo, a mãe coloriu com anilina a água do tanque e imergiu as galinhas legorne nessa água para pintá-las de várias cores: verde, azul, amarelo, vermelho, roxo, colorindo o quintal e povoando-o de histórias imaginadas pelos meninos. O narrador reflete sobre suas lembranças, sinalizando como elas despertavam no menino a fantasia, fazendo-o se sentir príncipe: “Ficava tudo encantamento. Não havia livro, mesmo aqueles vindos de muito longe, com história mais bonita do que as que a mãe sabia fazer" (QUEIRÓS, 2004, p. 52). Talvez tenha sido a partir dessa ludicidade vivida na infância que o autor tenha adquirido a consciência reflexiva para afirmar, no Manifesto por um Brasil Literário², que "liberdade, afetividade, espontaneidade e fantasia são elementos que fundam a infância" (QUEIRÓS, 2009, p. 2).

2 QUEIRÓS, Bartolomeu Campos. Manifesto por um Brasil Literário. Parati, 2009. 
Em Ler, escrever e fazer conta de cabeça, as lembranças da mãe emergem carregadas pela lembrança do seu fazer diário, que representava, para o menino, mais do que os gestos queriam dizer:

Minha mãe, deitando as folhas de violetas e cobrindo com terra, dizendo serem mudas, era já mistério que me fazia estrangeiro. Arrancando o capim que nascia, intruso, entre a alface, a couve, o almeirão, minha mãe passava horas podando suas mágoas, enterrando suas tristezas, transplantando suas suspeitas. Depois, com o regador, ela fazia chover sobre os canteiros, ungindo os brotos. (QUEIRÓs, 2001, p. 79).

Percebe-se a representação da figura da mãe que, em atitudes metaforizadas no texto literário e personificadas em sentimentos de tristeza e mágoa, revelada com o poder de, ao "fazer chover" e não molhar as plantas -, dar vida aos brotos. São as figurações percebidas pela criança que permitem ao adulto ressignificá-las, reconstruí-las, trazê-las para o texto literário, acrescidas de doses poéticas, como o faz Bartolomeu Campos de Queirós. Nesse caso, é o adulto traduzindo, em palavras, no gesto de busca do vocábulo adequado, a poesia do instante que, por sua vez, se transforma na escrita poética. Apreendemos, nessas representações, a memória afetiva do escritor que, com extrema habilidade, percebe-a e ficcionaliza-a na escrita, estabelecendo relações que são construídas pelo contexto e pelas sensações que os fatos exerceram em suas lembranças.

A figura do pai também é representada através dos sentimentos que a convivência produziu no narrador. O pai, de poucas palavras, guardava a proteção com a família através do trabalho incansável; não dizia seu amor em palavras, mas, em seu exemplo e atitudes: "Lia-se o amor no corpo forte do pai, em seu prazer pelo trabalho, em sua mansidão para com os longos domingos" (QUEIRÓs, 2004, p. 25). A força da memória voluntária, que nos permite lembrar as coisas tais como as percebemos, aqui aparece mais uma vez na descrição da figura do pai como sendo o provedor da família com seu 
A memória e a infância revisitadas por Bartolomeu Campos de Queirós

Cássia Regina Machado Alves • Telma Borges

trabalho, o chefe da casa e que não se envolvia muito em brincadeiras com os filhos, conforme se pode perceber no trecho a seguir:

\begin{abstract}
O pai, homem calado, coçava sempre a cabeça, por longo tempo, como se estivesse fazendo carinhos no pensamento. Trabalhava muito e sem descanso. Havia sempre um arame para esticar, uma galinha para cortar as asas, uma tábua no curral merecendo mais um prego, uma planta carecendo de estaca para ganhar em altura. Aos domingos, ele assentava à sombra de uma árvore e ficava com o tempo. O tempo Ihe presenteava com o silêncio. [...] Falava pouco. Às vezes contava curtas histórias. [...] Retomava o silêncio, abria o canivete muito amolado, picava o fumo, lambia a palha, enrolava o cigarro e fumava. (QUEIRÓS, 2004, p. 38).
\end{abstract}

Apreendemos a poesia que é acrescentada, no momento da enunciação, ao fato experimentado pelo adulto que narra. No excerto acima, o autor utiliza-se de uma metáfora (fazendo carinhos no pensamento) para descrever um momento de isolamento do pai, o que faz com que o leitor elabore a imagem simbólica do que seria o pai do menino, compenetrado em seus pensamentos, refletindo, meditando sobre a vida.

A seguir, o narrador projeta para o leitor a imagem que a criança formulava do pai, através das sensações provocadas por essa imagem: o provedor da família, imagem própria das famílias tradicionais; o pai que trabalhava fora, mas que também realizava afazeres próprios da figura masculina na casa. Na sensação da criança, traduzida pelo adulto, o pai era uma figura silenciosa; alguém que não dizia muito, mas amava em silêncio e presenteava a família do seu modo, com seu trabalho. Aquele que gostava de saborear a solidão e o silêncio. Dessa forma, o autor situa-se no lugar e no tempo do adulto para enunciar, porém sem emitir teorias sobre a relação entre pai e filho. Apenas deixa emergir da memória o que viveu quando criança, fazendo sua releitura e deixando a cargo do leitor sua própria leitura, subsidiada pela experiência. A magia do texto intenta, pois, atingir o leitor e despertar-lhe sua 
própria memória, seja através de sua história de vida, seja através das imagens construídas no discurso literário.

No fragmento abaixo, de rara beleza memorialística, o narrador de Indez aciona sua memória voluntária para evocar a lembrança de um tempo que, pela descrição, poderia se parecer com uma lacuna, um tempo de ausência, um tempo em que a família se tornava vulnerável. No entanto, com habilidade extrema, reescreve o momento pela emoção, reelabora o sentido do vivido trazendo, no discurso, a beleza que se situa, digamos, por detrás da realidade e que só o autor, como adulto, pode enxergar. Aqui, são sonho e fantasia que o autor carrega consigo para transformar e para ressignificar suas lembranças através do texto literário, realçando o lugar de onde provém a enunciação. $O$ autor narra uma ausência que era compensada pela perspectiva da presença. A ausência se faz poesia para tornar a presença mais doce e bela:

De tempo em tempo ele viajava por mais dias. A mãe amarrava as portas e janelas mais cedo, encostando machados e bacias. O medo lembrava que o pai estava ausente. Quando voltava, ele trazia pão com salame embrulhado em papel pardo. Naquele lugar, onde biscoitos e bolos eram frequentes, pão era notícia de outro mundo. E o salame, vermelho, cortado em rodelas, com meias-luas de pimenta-do-reino, tinha gosto do amor que o pai revelava nos gestos, mas não dizia com a voz. (QUEIRÓS, 2004, p. 38).

É importante observarmos nessa passagem o medo funcionando como um rastro (GAGNEBIN, 2014) daquele cuja ausência se materializa no medo como marca, como presença. Nesse sentido, o medo é, a um só tempo, rastro e marca. Se por um lado denuncia a falta paterna, exigindo estratagemas que estabeleçam, ainda que minimamente, a segurança da família (amarrar portas e janelas, encostar machados e bacias), por outro lado, é uma marca, uma presença que assinala a ausência do pai, do homem da casa, daquele que protege. 
A professora, personagem também marcante na infância de Bartolomeu Campos de Queirós, aparece representada, em Indez, como Dona Aurora, que contava histórias ao final da aula começando sempre pela frase: "Eu não sei se vi, se ouvi, se morei lá..." (QUEIRÓS, 2004, p. 73). Interessante notar que o melhor da aula era seu final: as histórias que a professora contava e que despertavam o encantamento que o adulto ainda conserva. Nota-se que, nessa narrativa, prevalece a figura da professora, que se sobrepõe à da escola, como instituição em si. O narrador descreve o cenário da escola rural, a primeira escola do menino Antônio, mas o que se percebe fortemente são os rastros deixados nele pela professora, que é a personificação do carinho, do afeto, da sabedoria.

Em Ler, escrever e fazer conta de cabeça, o narrador-personagem inicia o livro com ênfase na escola, onde deveria aprender a ler, a escrever e a fazer conta de cabeça, e o que lhe marcou não foi o que a professora ensinava, mas sim como ela o fazia. O menino descobre novos sentimentos que a escola provoca através da figura da professora, Dona Maria Campos que, por sinal, é a mesma do conto "Foram muitos, os professores".

Como toda criança, Antônio, em Indez, era um menino que convivia com os medos, com as dúvidas, com as incertezas. O medo inicial que teve ao entrar para a escola logo foi se desfazendo, pelo acolhimento que teve da professora. Bartolomeu Campos de Queirós valorizava a afetividade no trabalho docente, e isso pode ser comprovado em suas narrativas de infância. As lembranças que o narrador-personagem tem da professora guardam a doçura do carinho e da recepção:

Fui acolhido por Dona Maria Campos, minha primeira professora, com livro de chamada, caderno com plano de aula, encapado com papel de seda. No pátio ela nos leu da cabeça aos pés, conferindo a limpeza do uniforme, as unhas lavadas, o cabelo penteado. Pela primeira vez me senti o seu livro. [...] Fui o primeiro da fila. Dona Maria Campos segurou minha mão e a fila foi andando em direção à sala de aula. Mão fina e macia como o algodão da paineira, que 
minha mãe colhia aos tufos e costurava travesseiro com cheiro de mato. Meu coração disparou de amor e mão. (QUEIRÓS, 1997, p. 30-31).

Percebemos que o sentimento do menino pela professora se confunde com o sentimento que guarda pela mãe, embora o narrador-personagem dê a entender que percebe a diferença simbólica entre essas duas figuras, pela narrativa do adulto que ressignifica seu olhar de criança. A professora, com os instrumentos de ensino (livro de chamada e caderno de plano de aula), fazia o menino sentir-se seu livro, ou seja, um elemento próprio da escola. A ação de conferir as condições de higiene das crianças, pela professora, também foi recebida pelo menino como uma ação diferente da ação da mãe que, em casa, tem também, para com filhos, esse zelo.

Mencionando novamente as mãos, observamos que são elas que fazem essa conexão afetiva na vida do narrador-personagem. As mãos da professora, que seguram com firmeza a mão da criança, são como as mãos da mãe, que cuidam, que protegem, que transmitem segurança. Ambas - professora e mãe - exprimem seu amor através do cuidado que suas mãos oferecem ao aluno e ao filho. O simples toque da mão da professora representa, para ele, essa afetividade que o adulto julga imprescindível ao professor no ofício de ensinar. Aqui, novamente, as mãos; sempre as mãos!

A professora exerce influência quase que sagrada no menino, que a via como um anjo, carregando a delicadeza dos gestos, dos movimentos. O tema frequente é retomado. Neste excerto, as mãos da professora são sempre limpas; são mãos que escrevem no quadro e que exercem a função de ensinar, de tornar possível o aprendizado:

A professora gostava de vestido branco, como os anjos de maio. Carregava sempre um lenço dobrado dentro do livro de chamada ou preso no cinto, para limpar as mãos, depois de escrever no quadro-negro. Paninho bordado com flores, pássaros, borboletas. 
Ela passava o exercício, e de mesa em mesa ia corrigindo. Um cheiro de limpeza coloria o ar quando ela passava. (QUEIRÓS, 1997, p. 44).

Junto com as lembranças do período escolar, ele nos relata momentos com a família, particularidades de uma vivência que se dava entre a casa familiar e a casa do avô, figura marcante dessa fase de sua infância, que o faz recuar a um passado ainda mais remoto. No conto, o autor relembra experiências vivenciadas na casa do avô, que escrevia nas paredes da casa e era considerado, por ele, uma espécie de professor do cotidiano; as paredes eram repletas de histórias sobre "amores desfeitos, madrugada e fugas, casamentos e traições, velórios e heranças" (QUEIRÓS, 1997, p. 27). Tais histórias seduziam o menino, que as lia nas paredes que ele considerava seu primeiro livro:

\begin{abstract}
E suas paredes mais se enchiam de avisos sobre o mundo e as fronteiras do mundo. Eu decorava tudo e repetia timidamente. Eram tranquilas suas aulas, e o maior encanto estava em meu avô cultivar as dúvidas. Se ele escrevia "o mundo é uma bola besta sem eira nem beira", eu desconfiava se estava dizendo ser a terra redonda ou se a Terra era uma piada sem tamanho. Eu concluía ser as duas coisas. (QUEIRÓS, 1997, p. 29).
\end{abstract}

Mais uma vez, uma personagem marcante na infância do autor é rememorada através do sentimento que virou lembrança. O avô registrava nas paredes a história do local, guardando, por meio da escrita, uma memória coletiva do grupo no qual se inseria. A escrita aqui era concebida como prática histórica e social e o menino percebia isso de forma bem ampla, entendendo serem as paredes um caderno no qual se podia ler o mundo. O mundo, para ele, era o local, era a cidadezinha, era a casa do avô, era o que ele conhecia e do que participava.

Além disso, avô e neto são sujeitos capazes de potencializar a linguagem, dar sentido à palavra escrita, e expandir os significados 
das frases e orações. Nesse exercício, a criança incorpora a palavra não apenas como um sinal gráfico, mas também como uma forma de expressão da linguagem, que tem relevância e sentido no processo de comunicação. Bartolomeu Campos de Queirós dizia que "A educação se faz pela liberdade. Liberdade que você dá ao outro para que ele escolha o seu destino" (QUEIRÓS, 2011). Quando lemos que as aulas, para o menino, eram tranquilas, e que ele podia cultivar as dúvidas, percebemos muito do adulto fazendo uma releitura de si, de sua infância. Isso nos leva a refletir sobre a liberdade que lhe foi proporcionada pela professora; senão, suas lembranças não seriam tão afetuosas. As crianças cultivam dúvidas em relação a tudo, a si mesmas, às coisas, ao mundo; é tendo liberdade para duvidar que elas têm a ousadia para fazer suposições e para tentar desvendar os mistérios que as afligem:

O meu avô brincava muito comigo usando as palavras. Ele escrevia "azul" e me pedia para escrever outra palavra na frente. Eu escrevia "preto". Ele falava: "O azul hoje é quase preto". Ele fazia uma frase usando as duas palavras. Eu ficava incomodado como ele, com toda a palavra, dava conta de fazer uma frase. Com duas palavras, construía uma oração. (QUEIRÓS, 2012, p. 16).

Aqui, a capacidade de releitura e de ressignificação do adulto, ao rememorar, nomeia os gestos de escrita do avô; o presente dá condições para se interpretar e para se nomear os gestos do passado. A atitude do avô de brincar com as palavras era um gesto marcado pela espontaneidade da convivência, que transmitia seu próprio encantamento pelas palavras e conduzia a criança ao caminho do mundo poético. Com a poesia, o poder de transformação dos sentidos se amplia. Quando o avô formula a frase "o azul hoje é quase preto", ele está fornecendo ao menino uma possibilidade nova de pensar com liberdade para atribuir novos sentidos e caminhos para a palavra.

A representação do pai, da mãe, do avô e da professora evidencia a importância dessas figuras sobre os sentimentos do autor. Bartolomeu Campos de Queirós nos apresenta essas persona- 
gens da sua infância, não de forma humanizada, com traços físicos (cor da pele, dos cabelos e dos olhos, estatura etc.); ele as representa pelo que elas significaram em termos sentimentais, com os elementos que marcaram sua infância. Portanto, podemos dizer que ele transforma essas personagens em imagens poéticas carregadas de expressividade e são construídas por meio de uma linguagem que une prosa e poesia - estilo que ele habilmente utiliza em grande parte de sua obra para revestir o cotidiano com beleza e encantamento, assim como faz com essas personagens.

Mais do que relembrar suas histórias, narrando-as através da linguagem literária, o memorialista as organiza e (re)interpreta-as, reinventando-as e reencontrando-se naquele tempo e espaço. No exercício da escrita, o autor também passa por uma releitura de si; conquanto, ao se situar como parte integrante da narrativa, produz essa releitura ao se confrontar com a realidade do momento da enunciação e com o passado vivido. Assim, ele conjuga na linguagem escrita os sentimentos produzidos à época em que ocorreram os fatos narrados e aqueles provocados no ato da escrita. É a presentificação do afeto transmutado em escrita.

Acreditamos não ser a memória um simples depósito de imagens, datas ou eventos, mas algo que nos permite a compreensão das intenções que as lembranças carregam. Certamente, esse exercício foi incansavelmente praticado por Queirós, no esforço de reconstruir os cenários e as cenas cotidianas da sua infância, utilizando-se da ficção para preencher as lacunas causadas pelo esquecimento de um ou de outro fato, o que é explicável pela distância temporal existente entre a infância e o momento da escrita.

Conforme postula Ana Maria Barrenechea, "a memória é constantemente invadida pelo sonho e pela imaginação e, posto que existe a tentação de acreditar na realidade do imaginário, acabamos por transformar a nossa mentira em verdade." (BARRENECHEA, apud BORGES, 2011, p. 54). Queirós acrescenta às suas memórias tanto o sonho quanto a fantasia, por acreditar ser a fantasia sua verdade mais profunda. E acrescenta, em entrevista à Revista 
A memória e a infância revisitadas por Bartolomeu Campos de Queirós Cássia Regina Machado Alves • Telma Borges

Palavra, que "a fantasia é aquilo que não conto para ninguém, só para as pessoas que amo muito" (QUEIRÓS, 2012, p. 19).

Aquelas personagens - pai, mãe, professora e avô - são rastros que se apoderam do autor, como diria Walter Benjamin, como lampejos "num instante de perigo". São a presença de um passado desaparecido que faz sua irrupção no presente da escrita. (BENJAMIN, 1992, p.160).

Gostaríamos de finalizar retomando a figura do avô, que nos parece paradigmática na vida do escritor. Esse avô não deixou tesouros materiais, a despeito de ter tirado a sorte grande na loteria, mas a preciosa experiência de escritos na parede, os quais inspiram, impulsionam a escrita do neto Bartolomeu. Os escritos nas paredes - palavras transmitidas pelo avô transubstanciadas pelo neto em literatura, chegam aos leitores como uma tradição, como experiência compartilhada, que transcende os espaços da intimidade (casa) vivenciada nessa relação filial. Nesse sentido, Queirós é tido como herdeiro do que o avô escrevera nas paredes e nós somos herdeiros dessa experiência transposta para os livros dos quais somos leitores. A aliança se estabelece pelo acesso à palavra: do avô ao neto; do neto aos leitores. Como diz Aleida Assmann, a escrita seria o "rastro privilegiado que os homens deixam de si mesmos (ASSMANN, apud GAGNEBIN, 2014, p. 111). A escrita de Bartô, como era chamado por alguns, seria esse rastro que nos deixa de herança ou, melhor dizendo, uma tradição compartilhada pela experiência da escrita.

\section{Referências}

BACHELARD, G. A dialética da duração. Tradução Marcelo Coelho. 2. ed. São Paulo, Ática, 1994.

BENJAMIN, Walter. Teses sobre o Conceito de História. In: Sobre

Arte, Técnica, Linguagem e Política. Trad. Maria Luz Moita, Maria Amélia Cruz e Manuel Alberto; Prefácio de Theodor 
Adorno. Lisboa, Antropos, 1992.

BORGES, Telma. A escrita bastarda de Salman Rushdie. São Paulo, Annablume, 2011.

CANDAU, Joël. Memória e identidade. Trad. Maria Leticia Ferreira. São Paulo, Contexto, 2011.

GAGNEBIN, Jeanne Marie. Lembrar escrever esquecer. 2. ed. São Paulo, Editora 34, 2014.

HALBWACHS, Maurice. A memória coletiva. Trad. Laurént Léon Schaffter. São Paulo, Editora Revista dos Tribunais, 1990.

MINO, Sulla. Superstições - Parte I. O Mossoroense, Mossoró, RN, n, 16024, 21 abr. 2012. Disponível em: http://p.download.uol. com.br/omossoroense/mudanca/pics/pdf/EDICAO_210412.pdf. Acesso em: 20 dez. 2015.

QUEIRÓS, Bartolomeu Campos de. Indez. São Paulo, Global, 2004.

QUEIRÓS, Bartolomeu Campos de. Ler, escrever e fazer conta de cabeça. Belo Horizonte, Miguilim, 2001.

QUEIRÓS, Bartolomeu Campos de. Foram muitos, os professores. In: ABRAMOVICH, Fanny (Org.). Meu professor inesquecível. São Paulo, Editora Gente, 1997. p. 25-33.

QUEIRÓS, Bartolomeu Campos de. Manifesto por um Brasil literário [Paraty: s. n.], 2009. Disponível em: http://www. brasilliterario.org.br/manifesto.php. Acesso em: 25 mai. 2015. SEIXAS, Jacy Alves de. Percursos de memórias em terras de história: problemáticas atuais. In: BRESCIANI, Stella; NAXARA, Márcia (Orgs.). Memória e (res)sentimento: indagações sobre uma questão sensível. Campinas, Editora da Unicamp, 2009. p. 37-58.

YATES, Frances Amelia. A arte da memória. Trad. Flávia Bancher. Campinas, Editora da Unicamp, 2007. 
A memória e a infância revisitadas por Bartolomeu Campos de Queirós

Cássia Regina Machado Alves • Telma Borges

YUNES, Eliana. Memórias de Menino: poesia e melancolia.

Revista Palavra, Rio de Janeiro, ano 4, n. 3, p. 36-39, 2012.

Disponível em http://www.sesc.com.br/portal/publicacoes/ cultura/revistas/revista+palavra/revista_palavra_2012/revista_ palavra_2012. Acesso em: 12 jan. 2015. 